\title{
Effect Of Succession Planning On Leadership Elevation
}

\author{
Ammad Zafar \\ \& \\ Ghazal Khawaja Hummayun Akhtar \\ Department of Public Administration \\ University of Karachi
}

\begin{abstract}
Performance of any organization depends on productivity of leadership. The leaders are responsible for effective utilization of organization's resources. The leader gives the directions to subordinate for accomplishment of task as per need. Study reveals, many organizations are lacking availability of leadership. Management people are not prepared to perform future assignment. However, succession planning can be an effective tool for development of future leadership. Succession planning is the process of identifying key area and position of organization. it helps organization in identification of potential leader and competencies required to complete assignment. Succession planning improve the ability of employee and evaluate its performance. The study aims to analyze relationship between succession planning and leadership elevation. A survey of 300 personnel was conducted through closed ended questionnaire based on five points Likert scale. $50 \%$ respondent belong to male and $50 \%$ to female. Convenience sampling is used to draw sample in the study. The study reveals succession planning has significant positive impact of 4.3 times on leadership elevation.
\end{abstract}

Keywords: Leadership Elevation, Succession Planning, Organization, individual development, Leader.

$$
\begin{aligned}
& \text { تلخيص }
\end{aligned}
$$

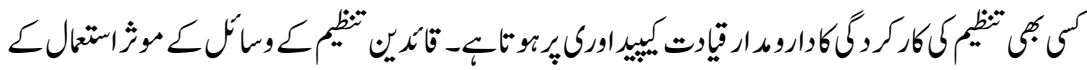

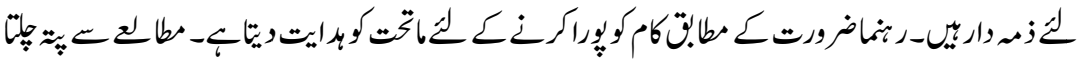

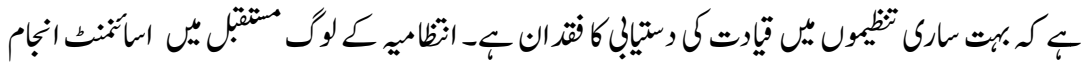

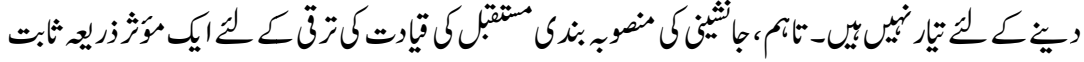

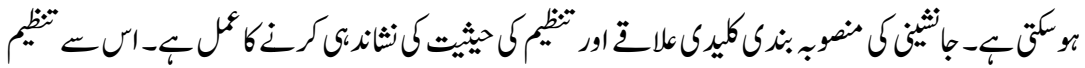

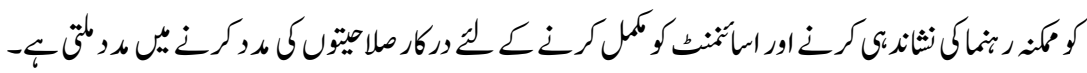

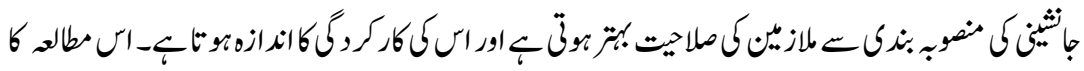

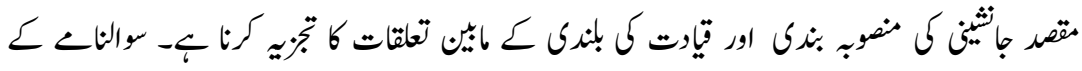

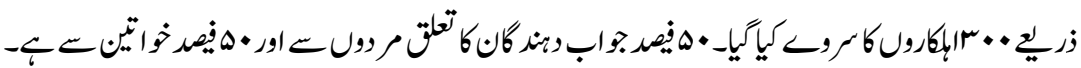

This work is Licensed under a Creative Commons Attribution-Non-Commercial 4.0 International License (c) (7) (5) 


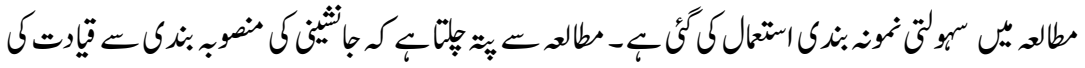

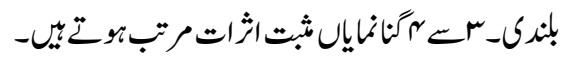

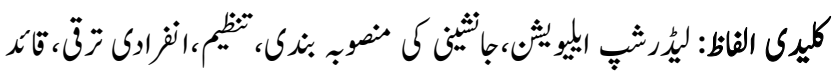

\section{Introduction}

The achievement of an organization is depending on the performance of existing leadership. The leader is responsible for the advancement of the organization and human capital, and furthermore convention of organization and dynamic ordering. Northouse (2010) characterized leadership as a procedure of impact devotee to accomplish a long-term goal of the organization. Moreover, it is the principle drive prompting organizational viability (Avolio, 1999; Rowe, 2001).Leaders are allowed to lead the office, not on the grounds that they are delegated by top administration; but since they are chosen by subordinates to lead the task or organization(Boseman, 2008). However, personnel ought to include and take an interest with the subordinates to accomplish organizational goals. In this manner, a leader must concentrate on the necessities of subordinates, both inside and outside the organization to assure that they are reliably pushing ahead towards the shared objective.

Perlmutter (2012) discussed, a leader experiences numerous stages and to turn into an effective leader he should follow a system cautiously; the main stage is known as Evaluation, here a leader assess the situations, advertise, capital, accomplices and the current state before arranging a line of activity or before going into the serious market. The subsequent stage is known as negotiation, here a powerful leader distinguishes his accomplices and convey to arrange a pleasing term to work and become together in the market. The third stage is known as the collaboration, here joint efforts are made by successful correspondence and arrangement skills, and the organization is under the direction of the leader begins to take its trip towards the development. Fourth stage is known as the innovation stage, this is the most essential stage and a large portion of the organizations don't arrive at this stage in light of absence of critical thinking, correspondence and negotiation skills. This is the stage a troublesome choice must be made. Advancement can be for the good of innovation or for the wellbeing of elevation, leader must distinguish either the organization needs inventive condition to develop or only for the market picture. For the most part leaders come up short in settling on the correct decision and winds up slamming the entire organization, the correct decision impact everything from the leader to the worker. The fifth and the last stage is to lift. In the wake of experiencing all the stages organization and the leader both are prepared to hoist. Here, the leader must connect the heights to 
continue hoisting in the market and keep the organization above water in the serious market. For the most part leaders neglect to fly between every one of the three elevations which therefore brings about the disappointment or compelling leadership.

Leadership elevation is improvement of parameters and making perspective for animating and organizing of individuals towards chose purposes. It fuses portions, for instance, training and development, speculation of individuals in dynamic, instructing, work strengthening and approval (Olrich, Goldsmith, \& Karter, 2005). Leadership development has gotten achievements in two before decades among which we can imply extending of organization development methods and coordination among the organization and laborers. Believing that leadership is something past organization ends up being more standard logically and makes more examinations based on leadership capacities and issues with respect to noncoordination in working endeavors and life(Hernez-Broome \& Hughes, 2004).

Leadership elevation experts are concentrating on new and advance procedures for Leadership elevation, for instance, informative ventures and instructing and apply them in fundamental issues. People could obtain basic aptitudes by coagulating such headings and reliable business conditions and thusly it is practical for relationship to find indispensable, coordinated and related issues and oversee them. Finally, explanation behind Leadership elevation consolidates action not data. As such, Leadership elevation at present methods giving learning opportunities to people through work not keeping them held from the work environment and obliging them to learning. Likewise, the best contribution of affiliations is to find the leadership work as a key factor in all activity levels and that they are set out to make ground-breaking pioneers over their affiliations. Developing increasingly individual and better pioneers isn't the fundamental reason for Leadership elevation even though this issue is as yet basic. Leadership is logically described such that it isn't just related to pioneer's exhibitions rather it is a method which makes another time of pioneers and amazing relations that their accentuation is on pioneers and accomplices' coordinated effort(Lajevardi \& Jamali, 2011).

It is critical to assure that there are an enough people who are all around prepared and accessible to accept a significant job inside the organization at whatever point required. Along these positions it is vital to persuade and prepare representatives to such an extent that they can take up new opening inside the organization as fast and as productively as conceivable with least conceivable damage to the organization(Clutterbuck, 2005). Developing leaders is a powerful and long-haul planning for an organization that takes into account the necessities of the organization as a piece of the vital bearing of the organization (Lowther \& Dexter, 2002). 
Studies of succession planning reveals, there is a need to take a look at role of leadership contrary to succession of the CEO. A couple of exploration examines have put an attention on including 'more elite class chiefs.' The explanation gave in these distributions to doing so is that these supervisors assume a significant role in creating approaches, executing and planning strategies, and in this manner assume a significant job in the presentation of the organization. Mackey (2008), states that the result of an organization is better evaluated by the top officials of the organization as opposed by people and lower-level staff individuals. This theory is upheld in a portion of the past works of Norburn \& Birley (1988), they present the theory that the presentation of the general organization can be evaluated by the exhibition of the top supervisory group of the organization. At the point when theory was joined with the theory gave by Parry \& Mason (2006), it brought about the extension of succession planning studies to explore on leadership role contrast to role of the CEO. Then again, another theory on succession planning states that succession planning of the organizational leadership ought to be learned at all degrees of the organization as it's anything but a stale procedure (Charan, Drotter, \& Noel, 2010).

\section{Problem Statement}

Studies of Rothwell (2011) has discussed unavailability of prospective leaders in many organizations located in USA. Fegley (2006)revealed only 6\% HR professional were prepared for the future assignment of the organization. Anon (2003) conducted a survey of 100 companies showed only $44 \%$ of companies have a planning to fill future need of organization. Unavailability of skilled people has become an important question to be addressed in the organization. As it directly influences the productivity of the organization. An effective succession plan is the key for future development of employee and organization. The Study has revealed $43 \%$ of organization has succession plan to prepare employee to meet future needs. Out of $43 \%$ organization that has plan, $34.60 \%$ respondents agreed that succession planning has role in development of future leadership.

\section{Research Question}

What is Leadership Elevation and How much it is influenced by succession planning?

\section{Research Objective}

The study aims to develop understanding about Leadership Elevation and examine the impact of succession planning on Leadership Elevation. 


\section{Review of Literature}

Leadership is one of those concepts that everybody has a thought of it. Everyone's natural thought may be somewhat not the same as anybody else's. In the leadership past concepts, various definitions have been given for the idea of leadership after some time. Most definitions portray leadership as an affecting procedure - as a procedure by which a few people motivate others to move in the direction of shared objectives. By definition, leaders lead others. Study along these lines characterize leadership as: the idea of the affecting procedure and its subsequent results that happens between a pioneer and devotees and how this impacting forms is clarified by the pioneer's dispositional qualities and practices, supporter discernments and attributions of the pioneer, and the setting where the affecting procedure happens (Antonakis \& Day, 2004)

Leadership Elevation is turning into an inexorably basic and vital basic for associations in the current business condition (Leskiw \& Singh, 2007). Leadership Elevation is a significant territory which is thought of and executed in associations to build human ability and some different advantages like to increase advantages for the organization. Some developmental tasks can be completed simultaneously with customary occupation obligations, while others require taking an impermanent leave from one's normal activity (Yukl, 2002). These development tasks can be utilized to create administrative abilities at current occupations, some might be utilized to grow new ventures or start new undertakings filling in as division delegate on a cross utilitarian groups. Instructional courses assume a significant job to improve the exhibition of hierarchical directors with respect to relational abilities, listening aptitudes, inspire others, bolster others, and exchange relevant information (Klagge, 1997).

A Leadership Elevation program is expected to improve the aptitudes of chiefs at all levels whether operational, strategic, key and individual also. Execution is a fundamental element of an association; besides, development projects can be useful in distinguishing and overseeing groups, where bunch development and explicitly self-improvement and development of chiefs additionally occur. The most significant perspective these days is that how a trough can receive the leadership properties and viably use them to play out his activity obligations doled out, these characteristics can assist him with working farther than the activity duties and add greater accomplishment to the association. Leadership Elevation process plans to create leaders and furthermore incorporates move of hierarchical culture and qualities eventually coming about into aggregate sharing among all the individuals from the association to accomplish the authoritative goals (Hamilton \& Bean, 2005). Leadership necessity in the present associations in Pakistani viewpoint is essential to address the worldwide business difficulties. Then again, Leadership Elevation is likewise a significant thought and challenge over the globe and affects representative's presentation. There is a lot of work 
done on Leadership Elevation and its effect on different components remembering worker execution for some pieces of the world, be that as it may, there is restricted examination led in Pakistan in view of which this significant zone of association and representative development stays unexplored on the loose.

Moreover, Tirmizi (2002) has given a 6-L system model of leadership innovative work in Pakistan and has built up a Leadership Elevation instrument dependent on $6 \mathrm{~L}$ structure. Then again, this investigation recognizes 6 measurements to be grown yet how to create stay unanswerable or the elements because of which Leadership Elevation can be led are not found yet gives an away from of significance and requirement for the Leadership Elevation in Pakistan. The six 6-L system measurements created by Tirmizi are: (i) Leads and encourage change (ii) Lives by example (iii) Lauds achievement (iv) Lends a vision (v) Leverages learning and development (vi) Looks out for others Many studies have concentrated distinctive types of leadership in significant organizational development Specially in new startup. It is helpful to sum up thought about leadership various concepts discussed in past research. Today, the 'full-extend leadership theory gives maybe the most generally utilized (despite the fact that by all account not the only) structure in leadership research (Bass B. M., 1985; Bass B. , 1998). The significant commitment by Bass and others was to move past pioneer qualities and characteristics to considering leadership styles, for example, transactional, transformational, instrumental, charming, and visionary leadership. Bass' (1985) hypothesis was basically a social hypothesis of leadership that concentrated on three significant classes of pioneer conduct: (a) transformational leadership, which clarifies esteem based, visionary, passionate, and charming pioneer activities, which are predicated on the pioneer's representative force; (b) transactional leadership, a compensation impacting process using reward and coercive force; and (c) free enterprise leadership, which really speaks to the nonattendance of leadership. This hypothesis was therefore stretched out by other people who included more leadership practices into the palette (Howell \& Avolio, 1993; Antonakis, Cianciolo, \& Sternberg, 2004). Thusly, this theory is all around bolstered, as noted in a few meta-investigations (Derue, Nahrgan, Wellman, \& Humphrey, 2011). Transformational leadership upgrades the inspiration, resolve, and execution of devotees with a scope of practices, for example, improving adherents' relationship with the task and the association and along these lines upgrading their feeling of responsibility for venture. Transformational leaders likewise go about as rousing good examples that adherents try to copy. Transactional leadership, then again, stresses observing and oversight. Transactional leaders set motivation instruments to boost wanted practices, yet they likewise intercede with sanctions whenever wanted execution isn't expected. In this manner, while transformational leadership is proactive, stresses recognizable proof with more significant standards and virtues and advances inventiveness and development in critical thinking, transactional leadership is responsive, works inside and fortifies a previously settled authoritative 
system, and advances to supporters' personal responsibility as opposed to higher goals (Bass B. M., 1985; Bass B. , 1998; Hackman \& Johnson, 2013). Transformational Leadership Elevation is influenced by an affective succession planning. The more effective succession planning an organization has the stronger Leadership Elevation the organization has (Ahmad, Mohamed, \& Manaf, 2019).

Succession planning and management should strengthen one another and go about as motivation for the employee development and creating prospective leaders. It furnishes with a stage to hold and support the organizational competitiveness, association need of proficient and successful managers to produce thoughts, to lift spirits and inspiration for progression of the association paying little heed to any difficulties ahead. Subordinate in association accept that a pioneer ought to have certain attribute. Workers make the assumption that the pioneer is the best model. Subsequently, pioneers need to show great conduct to pick up the certainty of subordinate. This current circumstance requires an upper hand as well as morals, commitment and making a workplace that is protected and reasonable (Rothwell W., 2005).

\section{Hypotheses}

The study design consists of qualitative and quantitative approach. The study has established three hypotheses to meet the objective of research. These hypotheses are analyzed through various statistical tools.

$\mathrm{H}_{10}$ : Leadership Elevation is independent of gender variation.

$\mathrm{H}_{1}$ : Leadership Elevation dependent on gender variation.

$\mathrm{H}_{20}$ : Succession planning has no association with Leadership Elevation.

$\mathrm{H}_{2}$ : Succession planning has significant association with Leadership Elevation.

$\mathrm{H}_{30}$ : Succession planning has no significant impact on Leadership Elevation.

$\mathrm{H}_{3}$ : Succession planning has significant impact on Leadership Elevation.

\section{Methodology}

The study is based on primary data collected through survey of 300 respondents. People working on management position or engaged in official assignments were selected for interview through convenience sampling in the region of Karachi city. An electronic copy of close ended questionnaire based on five points Likert Scale ranging from Strongly Disagree to Strongly Agree, was distributed among the respondent via email and social media messages in August 2019. A pilot study of questionnaire was done to verify reliability of questionnaire. Fifteen research scholars, having experience in the field of management science were interviewed for collection of their opinion about reliability and relevancy of questions of questionnaire. The questionnaire was consisting on questions about respondent's 
personal attribute, succession planning, organizational growth and Leadership Elevation. Study has drawn 50\% sample from male and 50\% from female. Study used multiple statistical tools to analyze data and examine the relationship between dependent variable and independent variable. Crosstab analysis was used to understand proportion of Leadership Elevation due to succession planning. Independent $t$ - test was used to analyze effect variation of gender on the process of Leadership Elevation. Study also used Chi-square test to verify association between variable. Impact of independent variable was calculated through binary logistic analysis. Study reveals succession planning is an important factor to improve process of Leadership Elevation. Study also reviewed literature on succession planning and its influence on Leadership Elevation. An effective succession plan is a series step. It includes plan of employee development. Employee development is the process of enhancing the abilities of employee to prepare them for future challenges.

\section{Analysis and Discussion}

Gender is one of important factor that need to be addressed in organization. Many studies reveal that equal employment opportunity given to employee irrespective to gender protect process of future Leadership Elevation process on its effect. In this study $50 \%$ respondent are male and remaining 50\% respondent belongs to female gender (See Figure 1).

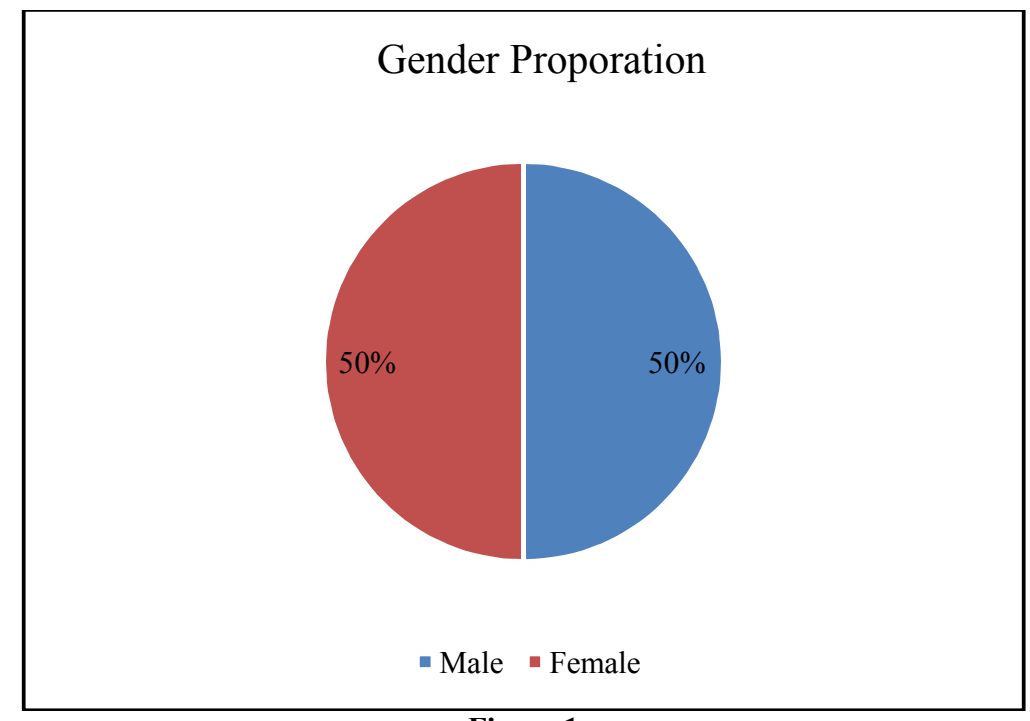

Figure 1

Studies reveals success of any organization is depend on effectivity of management plan implemented for the achievement of organizational objectives. In this study $43 \%$ respondents agree that their organization have succession plan 
that guide the organization for the future development of organization. 57\% respondents do not agree that their organization have any formal plan (See Figure 2).

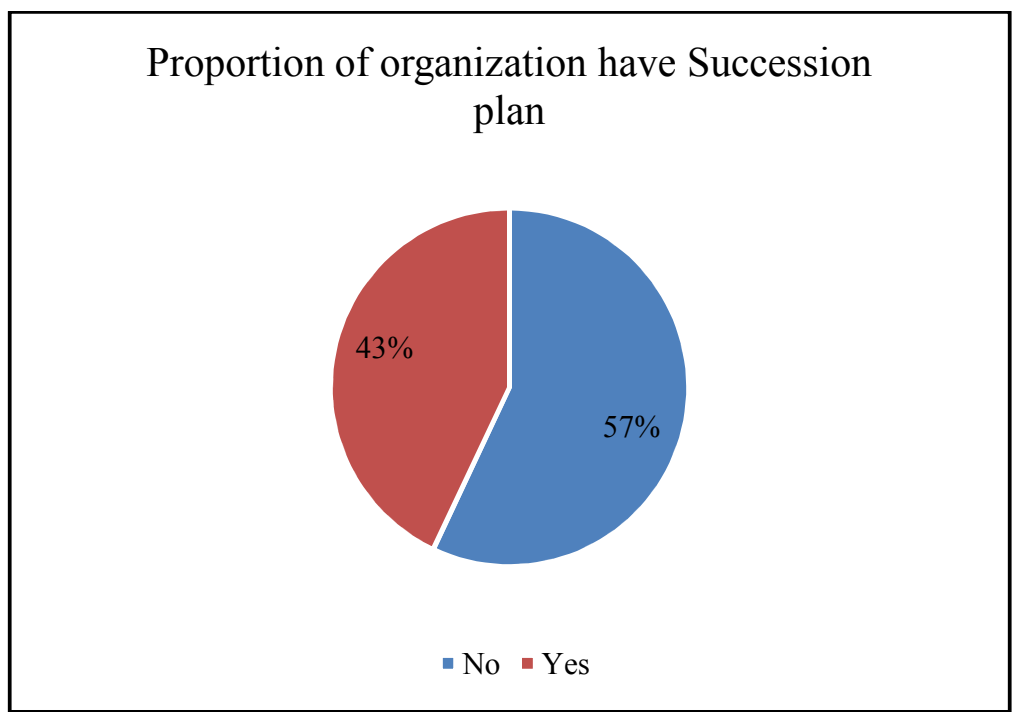

Figure 2

The Study reveals $76 \%$ of organization has process for the development of future leadership. they have proper plan for enhancing the ability of employees. Many researcheshave been conducted that reveals those organization which has process for development of prospective leader are more likely to survive in market for longer period (See Figure 3).

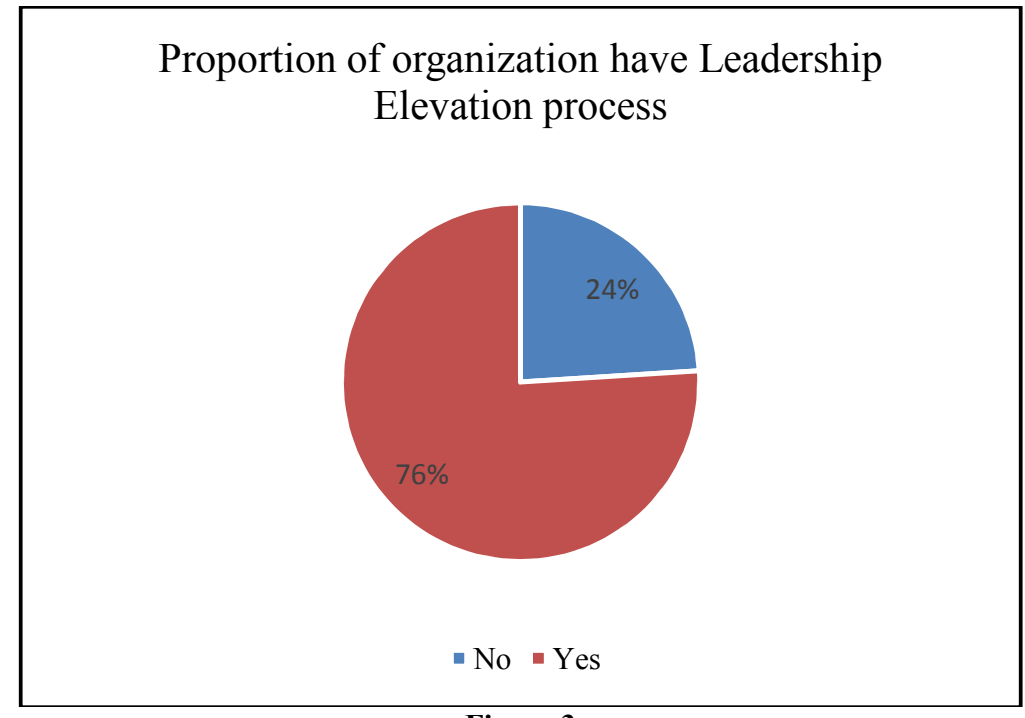

Figure 3 
Study reveals $34.60 \%$ respondents agree succession planning has an important role in the development of future leadership. Although majority of respondent disagree with the statement i.e. $65.40 \%$ respondentsagree succession planning has no role in their organization specifically for the development of future leadership. In many studies research pointed out that many organizations prefer to hire a person from outside the organization rather than promoting a person within the organization. So, the role of succession planning in those organization are not affecting process of Leadership Elevation.Study reveals more than 30\% respondents agree succession planning is an import factor in the development of prospective leadership (See Figure 4).

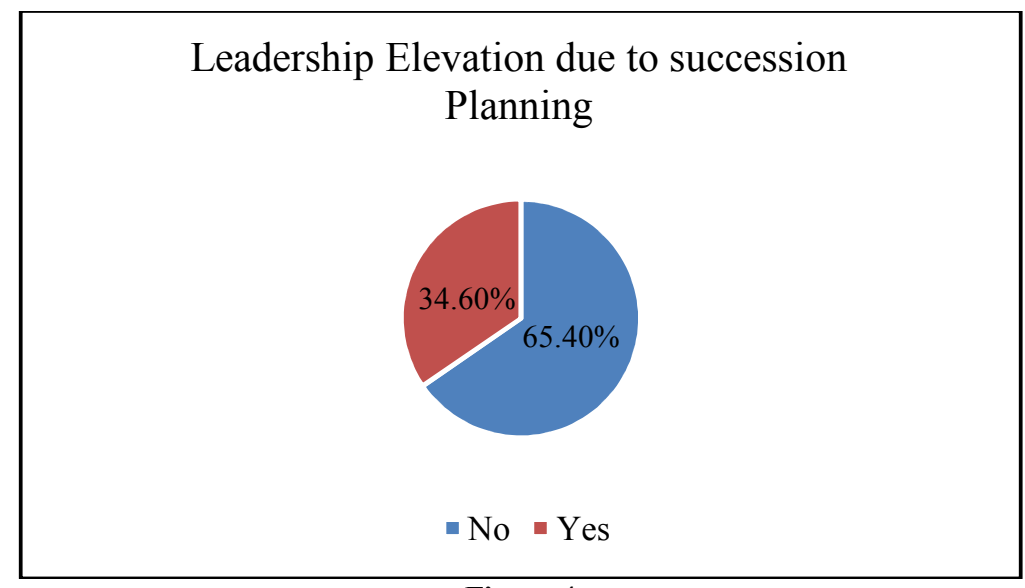

Figure 4

\section{Independent Samples $t$ - Test}

Analysis of group statistics for Leadership Elevation shows equal sample of male has nearly similar standard deviation (See Table: 1). The mean of male sample has also proximity with mean of female sample. Study reveals mean of male sample is related the mean of sample population. As sample represent population. So, study can conclude mean of both populations are similar. Various studies have discussed in case of similar mean population variation do not affect dependent variable.

Table: 1

Group statistics for leadership elevation

\begin{tabular}{|l|c|c|c|c|}
\hline $\begin{array}{l}\text { Gender's } \\
\text { Respondent }\end{array}$ & $\mathrm{N}$ & Mean & Std. Deviation & $\begin{array}{c}\text { Std. Error } \\
\text { Mean }\end{array}$ \\
\hline Male & 150 & 0.727 & 0.447 & 0.036 \\
\hline Female & 150 & 0.793 & 0.406 & 0.033 \\
\hline
\end{tabular}

Independent $\mathrm{t}$ - test is used to examine similarity of means of two sample extracted from different population (Kim, 2015). Analysis of $\mathrm{t}$ - test for equality of means shows a statistically insignificant result (See Table: 2 ). The p-value of 
test is greater than 0.05. that interpret we fail to reject null hypothesis i.e. gender variation has no association with process of Leadership Elevation. Based on result we can interpret. Any organization identifies potential leaders and give them training to meet future requirement of organization can be male or female. It has not evidence that male or female can have superiority on acquiring qualities of future leader. Organization can place male or female on the key position of the company without any hesitation. Analysis also interpret if the opportunity of learning given to both genders. It will have same outcomes.

Table: 2

Independent sample test leadership elevation

\begin{tabular}{|c|c|c|c|c|c|c|c|c|c|}
\hline & \multicolumn{7}{|c|}{$\begin{array}{c}\text { Levene's Test for } \\
\text { Equality of Variances }\end{array}$} & \multicolumn{7}{|c|}{$\mathrm{t}$ - test for Equality of Means } \\
\hline & $\mathrm{F}$ & $\mathrm{Sig}$ & $\mathrm{t}$ & $\mathrm{df}$ & $\begin{array}{c}\text { Sig. } \\
\text { (2-tailed) }\end{array}$ & $\begin{array}{c}\text { Mean } \\
\text { Difference }\end{array}$ & $\begin{array}{c}\text { Std. Error } \\
\text { Difference }\end{array}$ & $\begin{array}{c}95 \% \text { Confidence } \\
\text { interval of the } \\
\text { difference }\end{array}$ \\
\hline & & & & & & & & Lower & Upper \\
\hline $\begin{array}{c}\text { Equal variances } \\
\text { assumed }\end{array}$ & 7.365 & 0.007 & -1.351 & 298 & 0.178 & -0.067 & 0.049 & -0.164 & 0.030 \\
\hline $\begin{array}{c}\text { Equal variances } \\
\text { not assumed }\end{array}$ & & & -1.351 & 295.3 & 0.178 & -0.067 & 0.049 & -0.164 & 0.030 \\
\hline
\end{tabular}

\section{Chi-Square Tests}

Chi-Square analysis of Succession planning and Leadership Elevation shows a significant association between both variables. The p-value of Chi-Square Tests is less than 0.05 (See Table: 3). It means result of analysis is statistically significant. Based on result we reject null hypothesis that claim no association of variable. Many researchers have identified a very clear and strong relationship between an effective formal planning / Succession Planning and Leadership Elevation in the organization. Studies of researcher have identified an effective succession plan include a process of employee development such as enhancing knowledge, skill and abilities of employee to achieve future objective of organization (Ugoni \& Walker, 1999).

Table: 3

Chi-square analysis for association between succession planning and leadership elevation

\begin{tabular}{|l|c|c|c|}
\hline & Value & df & $\begin{array}{c}\text { Asymptotic Significance (2- } \\
\text { sided) }\end{array}$ \\
\hline Pearson Chi-Square & $27.030 \mathrm{a}$ & 1 & 0.00 \\
\hline Continuity Correction & 25.629 & 1 & 0.00 \\
\hline Likelihood Ratio & 27.124 & 1 & 0.00 \\
\hline N of Valid Cases & 300 & 1 & 0.00 \\
\hline a 0 cells (0.0\%) have expected count less than 5. The minimum expected \\
count is 30.96
\end{tabular}




\section{Logistic Regression Analysis}

Logistic regression is statistical tool used to calculate intensity of variables (Zafar, Memon, \& Khan, 2018). It does not only explain relation of variable, but it also determines impact of independent variable on dependent variable (Park, 2013). It has two type of explanation. At first stage it explains model summary and at second stage it explains variables in equation. Logistic regression assumes all data is normally distributed and variable are categorical in nature. Study has transformed variables in categorical variable to meet the requirement of logistic regression. Two categories have been evolved such as 1,0 .

The model summary shows independent variable i.e. succession planning has explained 8.6\% variation in dependent i.e. Leadership Elevation. Many studies have revealed an effective succession plan can have positive impact on process of Leadership Elevation in the organization. Zafar \& Akhtar (2020), have discussed succession plan has positive outcomes on its implementation for enhancing the ability of employee working in the organization. As model summary only $8.6 \%$ variation that means there are other variable which are affecting process of Leadership Elevation (See Table: 4).

Table: 4

Logistic regression model summary for analysis of succession planning and leadership elevation

\begin{tabular}{|c|c|c|c|}
\hline Step & $\begin{array}{c}-2 \text { Log } \\
\text { likelihood }\end{array}$ & $\begin{array}{c}\text { Cox \& Snell R } \\
\text { Square }\end{array}$ & $\begin{array}{c}\text { Nagelkerke R } \\
\text { Square }\end{array}$ \\
\hline 1 & $303.524 \mathrm{a}$ & 0.086 & 0.129 \\
\hline \multicolumn{3}{l}{$\begin{array}{l}\text { a Estimation terminated at iteration number } 5 \text { because parameter } \\
\text { estimates changed by less than } .001 .\end{array}$}
\end{tabular}

\section{Variable in Equation}

Binary logistic regression has analyzed the impact of succession plan on Leadership Elevation. It shows increase in effectivity of succession plan has 4.30 times positive impact on process of Leadership Elevation. The more effectivity of succession plan increases the more process of leadership develop improve. The result of analysis shows p-value is less than 0.05 (See Table: 5). We reject null hypothesis that there is no impact of succession planning on Leadership elevation. Studies reveal succession planning is an effective tool to enhance ability, skill and knowledge of employee through employee development program. 
Table: 5

Logistic regression analysis: variables in the equation for analysis of succession planning and leadership elevation

\begin{tabular}{|l|c|c|c|c|c|c|}
\hline & B & S.E. & Wald & df & Sig. & $\operatorname{Exp(B)}$ \\
\hline $\begin{array}{l}\text { Succession } \\
\text { Planning (1) }\end{array}$ & 1.455 & 0.291 & 24.974 & 1 & 0.000 & 4.30 \\
\hline Constant & 0.457 & 0.181 & 6.407 & 1 & 0.011 & 1.58 \\
\hline
\end{tabular}

\section{Conclusions}

Leadership Elevation is the process of enhancing the abilities, knowledge and skill of employees. It encourages employee to take self interest in organization. It provides opportunities to employee for his individual development. Studies reveal employee engage in employee development are more likely to perform better. Employee development program is a part Leadership Elevation process. It nurtures employee in all aspect as required by organization. Study concluded succession planning is an essential tool for Leadership Elevation. It has an impact of 4.3 times on the process of Leadership Elevation. The more effective succession plan an organization has the more strong process of Leadership Elevation will be. Study has showed significant association between succession planning and Leadership Elevation. Beside this study also depict there is no association of gender variation with process of Leadership Elevation.

\section{Recommendations}

- Study recommend all organization must do formal planning for the achievement of future objective

- Organization having succession plan must focus on effectivity of plan. So that It could affect more to the process of leadership elevation.

- Organization must start more employee development program to make employee better to perform.

\section{References}

Ahmad, R. B., Mohamed, A. M. \& Manaf, H. B. (2019). The Relationship Between Transformational Leadership Characteristic and Succession Planning Program in the Malaysian Public Sector. International Journal of Asian Social Science, vol.7:1, pp.19-30.

Anon. (2003). Softscape Survey of HR Executives Reveals 70 Percent Seeking to Prepare for Talent Crisis. Business Wire,. Retrieved from 
https://www.businesswire.com/news/home/20031008005104/en/Softscape -Survey-HR-Executives-Reveals-70-Percent

Antonakis, J. E., Cianciolo, A. T. \& Sternberg, R. J. (Eds.). (2004). The Nature of Leadership. Sage Publications, Inc.

Antonakis, J., \& Day, D. V. (2004). Leadership: Past, Present and Future. Sage Publications, Inc.

Avolio, B. J. (1999). Full Leadership Development: Building the Vital Forces in Organizations. Sage.

Bass, B. (1998). Transformational Leadership: Industrial, Military and Educational Impact. Lawrence Earlbaum Associates, vol.79:3, p.91.

Bass, B. M. (1985). Leadership and Performance Beyond Expectations. New York: Collier Macmillan.

Boseman, G. (2008). Leadership Effective Leadership in a Changing World. Journal of Financial Service Professionals, vol.62:3, p.36.

Charan, R., Drotter, S. \& Noel, J. (2010). The Leadership Pipeline: How to Build the Leadership Powered Company. John Wiley \& Sons.

Clutterbuck, D. (2005). Succession Planning: ADevelopmental Approach. Development and Learning in Organizations: An International Journal, vol.19:5, pp.11-13.

Derue, D. S., Nahrgang, J. D., Wellman, N. \& Humphrey, S. E. (2011). Trait and Behavioral Theories of Leadership: An Integration and Meta-Analytic Test of their Relative Validity. Personnel Psychology, vol.64:1, pp.7-52.

Fegley, S. (2006). 2006 Succession Planning Survey Report. Alexandria, VA: Society for Human Resource Management, pp.1-33.

Hackman, M. Z. \& Johnson, C. E. (2013). Leadership: A Communication Perspective. Waveland Press.

Hamilton, F. \& Bean, C. J. (2005). The Importance of Context, Beliefs and Values in Leadership Development. Business Ethics: A European Review, vol.14:4, pp.336-347.

Hernez-Broome, G. \& Hughes, R. J. (2004). Leadership Development: Past, Present and Future. Human Resource Planning, vol.27:1, pp. 24-32. 
Howell, J. M. \& Avolio, B. J. (1993). Transformational Leadership, Transactional Leadership, Locus of Control and Support for Innovation: Key Predictors of Consolidated-Business-Unit Performance. Journal of Applied Psychology,vol.78:6, p.891.

Kim, T. K. (2015). T Test as a Parametric Statistic. Korean Journal of Anesthesiology, vol.68:6, pp.540-546.

Klagge, J. (1997). Leadership Development Needs of Today's Organizational Managers. Leadership \& Organization Development Journal, vol.18:7, pp.355-362.

Lajevardi, J. \& Jamali, N. A. (2011). Relationship between Emotional Intelligence and Reference Style of Manager's Leadership. Journal of Management Perspective, vol.1.

Leskiw, S.-L. \& Singh, P. (2007). Leadership Development: Learning from Best Practices. Leadership \& Organization Development Journal, vol.28:5, pp.444-464.

Lowther, T. \& Dexter, W. (2002). Continuing ed: Defining Professional Development. Consulting-Specifying Engineer, vol.32:1, pp. 6-16.

Mackey, A. (2008). The Effect of CEOs on Firm Performance. Strategic Management Journal, vol.29:12, pp.1357-1367.

Norburn, D. \& Birley, S. (1988). The Top Management Team and Corporate Performance. Strategic Management Journal, vol.9:3, pp.225-237.

Northouse, P. G. (2010). Leadership: Theory and Practice (5th ed.). Thousand Oaks: Sage publications.

Olrich, Goldsmith \& Karter. (2005). Leadership Development and Organizational Changes, Translated by Moeeinodini. Tehran: Management Organization. http://www.ijbhtnet.com/journals/Vol_2_No_5_August_2012/17.pdf

Park, H.-A. (2013). An Introduction to Logistic Regression: From Basic Concepts to Interpretation with Particular Attention to Nursing Domain. Journal of Korean Academy of Nursing, vol.43:2, pp.154-164. 
Perlmutter, L. S. (2012). Transformational Leadership and the Development of Moral Elevation and Trust, University of British Columbia, pp. 60-72. Retrieved from https://open.library.ubc.ca/cIRcle/collections/ubctheses/ 24/items/1.0076999

Rothwell, W. (2005). Putting Succession Planning: Ensuring Leadership Continuity and Building Talent from Within (3rd ed.). New York: Amacom.

Rothwell, W. J. (2011). Replacement Planning: ASstarting Point for Succession Planning and Talent Management. International Journal of Training and Development, vol.15:1, pp.87-99.

Rowe, W. G. (2001). Creating Wealth in Organizations: The Role of Strategic Leadership. Academy of Management Perspectives, vol.15:1, pp.81-94.

Tirmizi, S. A. (2002). The 6-L Framework: AModel for Leadership Research and Development. Leadership \& Organization Development Journal, vol.23:5, pp.269-279.

Ugoni, A. \& Walker, B. F. (1999). The Chi Square Test: An Introduction. Comsig Review, vol.4:3, pp.61-64.

Yukl, G. (2002). Leadership in Organizations (5th ed.). Upper Saddle River: Prentice Hall.

Zafar, A. \& Akhtar, G. K. (2020). Effect of Succession Planning on Orgnizational Growth. Journal of Social Sciences and Humanities, vol.59:1, pp.21-33.

Zafar, A., Memon, A. \& Khan, M. N. (2018). Implication of HR Components on Employee Performance: A Comparative Analysis of Public \& Private Sector Employees. Pakistan Administrative Review, vol.2:2, pp.223-232.

Ammad Zafar is a Ph.D Scholar in the Department of Public Administration, University of Karachi, Karachi, Pakistan.

Dr. Ghazal Khawaja Hummayun Akhtar is an Assistant Professor in the Department of Public Administration, University of Karachi, Karachi, Pakistan. 